\title{
Analisis Pengaruh Penggunaan Visual Basic Application Terhadap Minat Belajar Matematika Siswa SD pada Materi Bilangan Prima
}

\author{
Ernawati $^{1}$, Leni Nurhayati ${ }^{2}$, Siti Chotimah ${ }^{3}$ \\ ${ }^{1.2 .3}$ Program Studi Pendidikan Matematika, IKIP Siliwangi, Jl Terusan Jenderal Sudirman Cimahi \\ 40526, Indonesia \\ E-mail: ernawati4298@gmail.com ${ }^{1}$
}

\begin{abstract}
Abstrak
Tujuan dari penelitian ini adalah untuk mendeskripsikan minat belajar matematika siswa kelas V SD pada materi bilangan prima dengan berbantuan media pembelajaran ICT yaitu Visual Basic Application (VBA)Excel. Metode penelitiannnya menggunakan penelitian desktiptif kualitatif. Subjek dari penelitian ini adalah siswa kelas 5 Madrasah Ibtidaiyah (MI) II Celak yang terdiri dari 26 siswa. Instrumen yang diberikan berupa angket skala minat belajar siswa yang terdiri dari 20 pernyataan, dengan masing - masing 10 pernyataan positif dan 10 pernyataan negatif dari lima indikator yaitu 1 ). Perasaan senang, 2). Ketertarikan siswa, 3). Keterlibatan siswa, 4). Rajin dalam belajar dan rajin dalam mengerjakan tugas matematika, 5). Tekun dan disiplin dalam belajar dan memiliki jadwal belajar. Berdasarkan hasil analisis data, diperoleh bahwa pembelajaran matematika menggunakan media VBA dapat meningkatkan minat belajar siswa. Hal tersebut ditunjukan oleh persentase dari masing - masing indikator minat belajar siswa. Indikator yang paling tinggi yaitu perasaan senang dan ketertarikan siswa dalam belajar matematika, masing - masing memperoleh hasil 87,02\% dan 89,18\% yang menunjukan bahwa minat belajar siswa dalam belajar matematika sangat tinggi.
\end{abstract}

Kata Kunci: minat belajar, bilangan prima, VBA Excel

\section{Analysis of interest in Learning Elementary School on Prime Numbers Assisted by Visual Basic Application}

\begin{abstract}
The purpose of this study is to describe the interest in learning mathematics for fifth grade elementary school students on prime number material assisted by ICT learning media, namely Visual Basic Application (VBA) Excel. The research method uses qualitative descriptive research. The subjects of this study were 5th grade students of Madrasah Ibtidaiyah (MI) II Celak which consisted of 26 students. The instrument was given in the form of a questionnaire for students' interest in learning consisting of 20 statements, with 10 positive statements each and 10 negative statements from five indicators, 1). Feelings of pleasure, 2). Student interests, 3). Student involvement, 4). Diligent in studying and diligent in doing math tasks, 5). Diligent and disciplined in learning and having a study schedule. Based on the results of data analysis, it was found that learning mathematics using VBA media can increase student learning interest. This is shown by the percentage of each indicator of student interest in learning. The highest indicator is the feeling of pleasure and interest of students in learning mathematics, each getting $87.02 \%$ and $89.18 \%$ which shows that students' interest in learning mathematics is very high.
\end{abstract}

Keywords: learning interest, prime numbers, VBA Excel 


\section{PENDAHULUAN}

Perkembangan zaman dari waktu ke waktu semakin berkembang dengan pesat. Terlihat dari semakin majunya segala aspek dalam bidang kehidupan, khusunya IPTEK (Ilmu pengetahuan dan Teknologi). Perkembangan IPTEK menumbuhkan banyak tantangan baru di masa depan yang harus dihadapi oleh setiap negara. Untuk menghadapi tantangan tersebut setiap negara mau tidak mau harus siap dan melakukan perbaikan salah satunya dalam bidang pendidikan. Perubahan yang dilakukan negara Indonesia salah satunya adalah perubahan kurikulum pendidikan dari KTSP (Kurikulum Tingkat Satuan Pendidikan) 2006 menjadi Kurikulum 2013.

Penerapan kurikulum 2013 di Indonesia dilandasi oleh tantangan masa depan yangberupa Globalisasi: WTO, ASEAN Community, APEC, CAFTA; Masalah lingkunganhidup; Kemajuan teknologi informasi; Konvergensi ilmu dan teknologi; Ekonomi berbasispengetahuan; Kebangkitan industri kreatif dan budaya; Pergeseran kekuatan ekonomidunia; Pengaruh dan imbas teknosains; Mutu, investasi dan transformasi pada sectorpendidikan dan Materi TIMSS dan PISA (Kemendikbud, 2014; Nurfauziah \& Fitriani, 2019)

Matematika merupakan salah satu mata pelajaran yang sangat penting untuk dipelajari, karena tidak bisa dipungkiri kemajuan teknologi terjadi karena ditemukannya penemuan - penemuan baru di bidang matematika. Oleh karena itu, matematika harus dipelajari dari jenjang dasar sampai dengan perguruan tinggi. Namun pada faktanya matematika merupakan mata pelajaran yang ditakuti dan tidak diminati karena dianggap sulit. Seperti penelitian yang dilakukan oleh Siregar (Rahmawati, Bungsu, Islamiah, \& Setiawan, 2015)menyatakan bahwa persepsi siswa mengenai pembelajaran matematikadidapatkan hasil $45 \%$ yang menyatakan bahwa pembelajaran matematika itu sulit. Kemudian menurut Marfuah (Rahmawati et al., 2015), matematika merupakan pembelajaran yang kurang diminati oleh siswa.Minat yang rendah terhadap matematika akan berimplikasi pada minimnya keinginan untuk mempelajari matematika(Widyastuti, Wijaya, Rumite, \& Marpaung, 2019).

Menurut Aritonang (Putri, Hasnita, Vilardi, \& Setiawan, 2019)minat besar sekali pengaruhnya terhadap belajar karena dengan minat seseorang akan melakukan sesuatu yang diminatinyadan sebaliknya, tanpa adanya minat seseorang tidak mungkin melakukan sesuatu.Hal tersebut sejalan dengan yang dikatakan Dores, Huda, Riana, \& Persada (2019)Minat sangatlah berpengeruh besar terhadap belajar, karena bila bahan pelajaran yang dipelajari tidak sesuai dengan minat siswa, siswa tidak akan belajar dengan sebaik-baiknya, karena tidak ada daya tarik bagi siswa untuk belajar.Khairani (Widyastuti et al., 2019) menyatakan terdapat tiga faktor yang mempengaruhi minat yaitu, the factor inner urge berupa rangsangan yang datang dari lingkungan atau ruang lingkup yang sesuai dengan keinginan atau kebutuhan seseorang; the factor of social motive berupa sesuatu hal yang dipengaruhi oleh motif sosial serta emotional factor berupa faktor perasaan / emosi terhadap objek.

Untuk mengatasi rendahnya minat siswa, peran guru sebagai pembimbing dalam proses pembelajaran sangat penting untuk diperhatikan. Guru harus bisa menemukan solusi bagaimana cara supaya siswa mempunyai minat untuk belajar matematika dan mengubah anggapan matematika sulit menjadi matematika adalah mata pelajaran yang asik untuk dipelajari. Caranya, seorang guru harus bisa memberikanpembelajaran yang menarik yang akan membuat siswa tertarik dengan pembelajaran yangdisampaikan. Untuk itu dalam pembelajaran matematika tersebut perlu ada media yang digunakansebagai alat bantu dalampembelajaran agar pembelajaran tersebut bisa menumbuhkan minat belajardalam diri siswa (Putri et al., 2019). Menurut Asnawir dan Usman (Hanipa, Misbahudin, Andreansyah, \& Setiawan, 2019), fungsi penggunaan media pembelajaran adalah: 1) membantu belajar bagi siswa dan membantu mengajar bagi guru. 2) pengalaman lebih nyata bagi siswa (dari abstrak menjadi lebih konkrit). 3) menarik perhatian siswa (kegiatan pembelajaran lebih menyenangkan juga tidak membosankan). 4) mengaktifkan semua indra yang dimiliki siswa. 5) menarik perhatian dan minat siswa dalam belajar. Berdasarkan hal tersebut, penggunaan media dalam pembelajaran juga menuntut guru untuk menguasai ilmu pengetahuan dan teknologi sebagai upaya menjembatani meningkatnya pemahaman guru tentang materi yang diajarkan (Samura, 2015)

Menurut Bernard (Romlah, Nugraha, Nurjanah, \& Setiawan, 2019), media pembelajaran dalam matematika adalah alat untuk menggambarkan siswa bahwa mereka dapat memahami bagaimana menerapkan ke berbagai bentuk masalah yang berkaitan dengan matematika, salah satunya 
dengan menggunakan aplikasi VBA (Visual Basic Application). Visual Basic for Excel merupakan bahasa program Microsoft Excel yang dapat dimanfaatkan fungsi-fungsi matematika yang mengatur obyek-obyek gambar yang disebut Shapes untuk lebih interaktif (Bernard, 2018). Menurut Chotimah, Bernard, \& Wulandari, (Nurfauziah \& Fitriani, 2019)VBA Excelmerupakan aplikasi yang dirancang menjadi alat matematika yang menjadikan siswamenjadi lebih aktif, tidak memerlukan biaya, dan Microsoft office excel dapat diakses olehpengguna komputer. Selain itu juga, menurut Fitriani, Suryadi, \& Darhim,VBA Excel juga dapat meningkatkan kemampuan berpikir siswa(Nurfauziah \& Fitriani, 2019)

Selain dari pertimbangan diatas, Menurut Ghozi (Putri et al., 2019)ada lima pertimbangan yang penting didalam memilih aplikasi computersehingga dapat digunakan secara luas dalam pembelajaran, dimana aplikasi tersebut; (1) menggunakantampilan yang dinamis untuk menganalisis, (2) mengespresikan model yang personal, (3) mencarimodel, (4) menyediakan dan memproses data yang nyata, (5) membagikan danmengkomunikasikan. Berdasarkan pernyataan tersebut VBA merupakan aplikasi yang salah satunya memenuhi kriteria tersebut.

Berdasarkan uraian uraian diatas, penelitian ini bertujuan untuk menganalisis minat siswa dalam belajar matematika pada materi faktorisasi bilangan prima menggunakan media ICT VBA pada siswa Madrasah Ibtidaiyah.

\section{METODE}

Metode penelitian yang digunakan adalah metode survei berupa penyebaran angket skala sikap mengenai minat belajar siswa pada materi faktorisasi bilangan prima menggunakan media ICT yaitu aplikasi VBA. Populasi pada penelitian ini adalah Siswa Madrasah Ibtidaiyah di Kabupaten Bandung Barat, sedangkan sampelnya adalah 26 siswa kelas 5 MI II Celak. Instrumen yang digunakan berupa instrumen non tes yaitu berupa angket minat belajar siswa yang terdiri dari 20 pernyataan masing - masing 10 pernyataan positif dan 10 pernyataan negatif. Adapun instrumen angketnya dapat dilihat pada Tabel 1.

Tabel 1. Butir Skala Sikap Minat Belajar Siswa

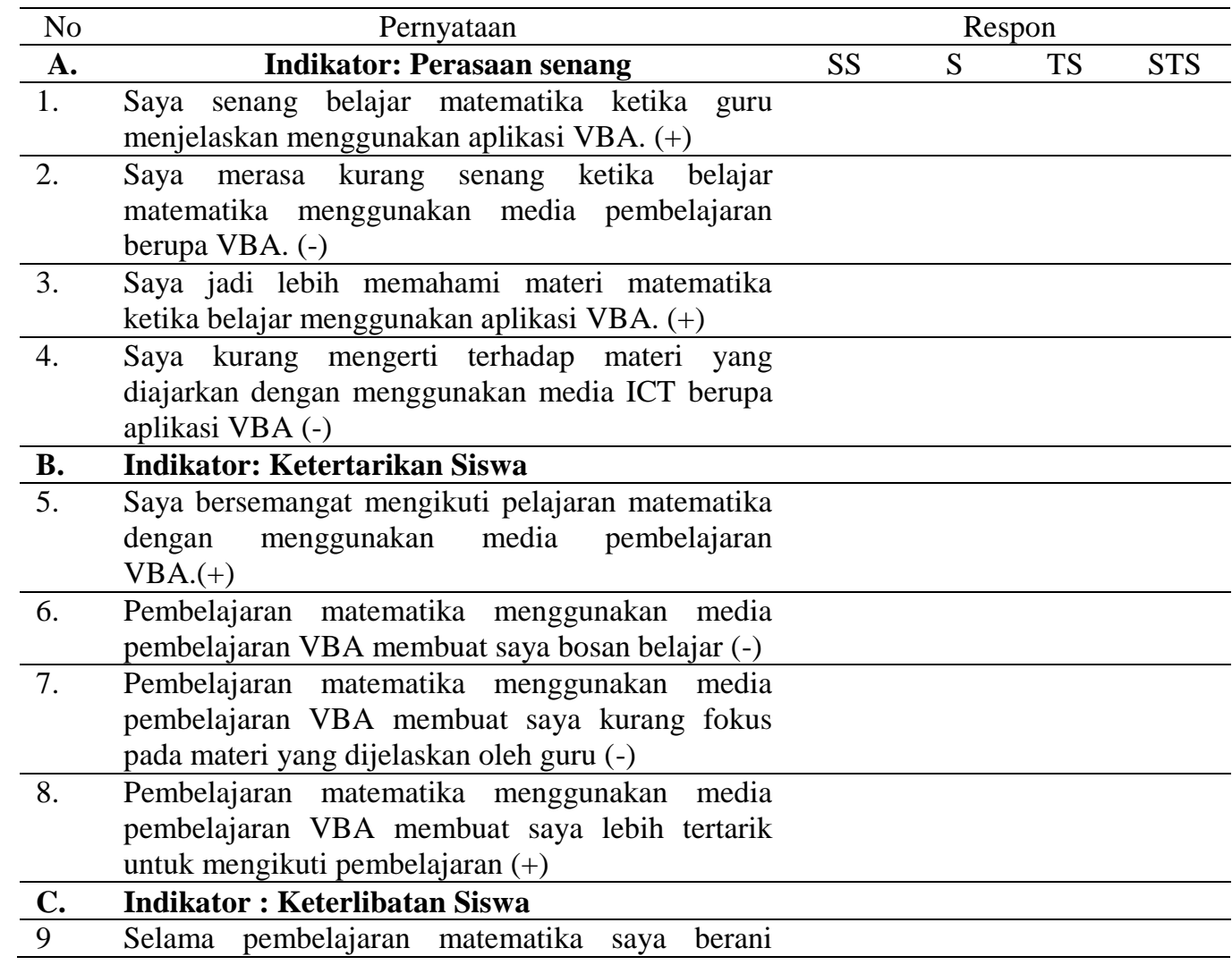




\begin{tabular}{ll}
\hline \multicolumn{3}{c}{ mengemukakan pendapat (+) } \\
\hline 10 & $\begin{array}{l}\text { Saya tidak percaya diri ketika disuruh mengerjakan } \\
\text { soal di depan kelas (-) }\end{array}$ \\
\hline 11 & $\begin{array}{l}\text { Saya malas membuat catatan matematika yang } \\
\text { sudah diajarkan (-) }\end{array}$ \\
\hline 12 & $\begin{array}{l}\text { Saya merasa tertantang untuk mengerjakan soal - } \\
\text { soal matematika yang tidak rutin (+) }\end{array}$ \\
\hline D. & $\begin{array}{l}\text { Indikator: rajin dalam belajar dan rajin } \\
\text { mengerjakan tugas matematika }\end{array}$ \\
\hline 13 & $\begin{array}{l}\text { Saya merasa malas mengerjakan tugas matematika } \\
\text { yang rumit (-) }\end{array}$ \\
\hline 14 & $\begin{array}{l}\text { Saya memilih soal latihan matematika yang } \\
\text { sederhana (-) }\end{array}$ \\
\hline 15 & $\begin{array}{l}\text { Saya memilih sendiri tugas matematika yang } \\
\text { menurut saya lebih menantang (+) }\end{array}$ \\
\hline 16 & Saya semangat mengerjakan tugas matematika (+) \\
\hline E. & $\begin{array}{l}\text { Indikator: Tekun dan disiplin dalam belajar dan } \\
\text { memiliki jadwal belajar }\end{array}$ \\
\hline 17 & $\begin{array}{l}\text { Saya berusaha menyelesaikan soal matematika } \\
\text { yang sulit meski perlu waktu lama (+) }\end{array}$ \\
\hline 18 & $\begin{array}{l}\text { Saya berusaha rutin belajar matematika sesuai } \\
\text { jadwal yang sudah saya susun (+) }\end{array}$ \\
\hline 19 & $\begin{array}{l}\text { Saya belajar matematika hanya ketika materi yang } \\
\text { dipelajari menurut saya mudah (-) }\end{array}$ \\
\hline 20 & $\begin{array}{l}\text { Saya malas belajar matematika ketika materinya } \\
\text { sulit untuk saya pahami (-) }\end{array}$ \\
\hline
\end{tabular}

Penskoran dari angket diatas disesuaikan dengan respon yang diberikan. Ada 4 respon yang bisa dipilih yaitu sangat setuju (SS), Setuju (S), Tidak Setuju (TS), dan Sangat Tidak Setuju (STS). Adapun skor dari setiap respon dapat dilihat pada Tabel 2.

Tabel 2. Skor Skala Sikap Minat Belajar

\begin{tabular}{lcc}
\hline \multirow{2}{*}{ Respon } & \multicolumn{2}{c}{ Skor } \\
\cline { 2 - 3 } & Positif & Negatif \\
\hline Sangat Setuju & 4 & 1 \\
\hline Setuju & 3 & 2 \\
\hline Tidak Setuju & 2 & 3 \\
\hline Sangat Tidak Setuju & 1 & 4 \\
\hline
\end{tabular}

Data hasil penelitian yang diperoleh kemudian diolah menggunakan Microsoft Excel. Adapun teknik pengolahannya menggunakan rumus persentase Sugiono (Putri et.al, 2019) yaitu:

$$
P=\frac{f}{n} \times 100 \%
$$

Keterangan:

$\mathrm{P}=$ persentase jawaban

$\mathrm{f}=$ frekuensi jawaban

$\mathrm{n}=$ banyak responden

Persentase yang diperoleh pada masing-masing item pernyataan, kemudian ditafsirkan berdasarkan kriteria pada Tabel 3 berikut (Putri et.al., 2019): 
Tabel 3. Kriteria Penafsiran Persentase Jawaban Angket

\begin{aligned} & \hline Kriteria \multicolumn{1}{c}{ Penafsiran } \\ & \hline $80 ; \mathrm{X} ; 100$ Sangat Tinggi \\ & 73,$33 ; \mathrm{X} ; 80$ Tinggi \\ & 53,$34 ; \mathrm{X} ; 73,33$ Sedang \\ & $40 ; \mathrm{X} ; 53,34$ Rendah \\ & $20 ; \mathrm{X} ; 40$ Sangat Rendah \\ & \hline\end{aligned}

\section{HASIL DAN PEMBAHASAN}

Kegiatan yang dilakukan selama proses pembelajaran yaitu:

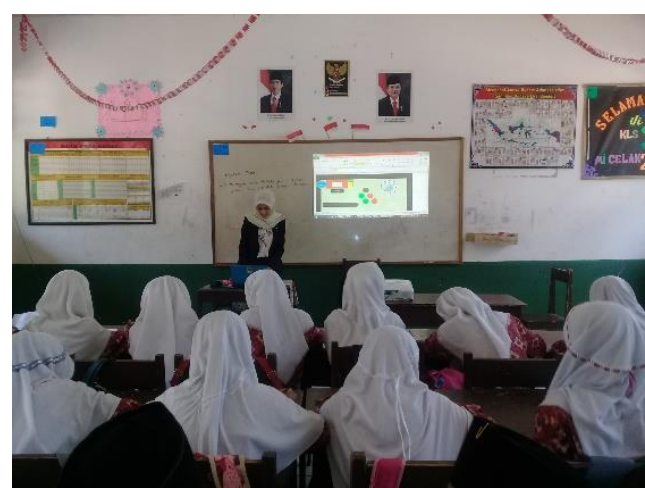

Gambar 1. Siswa Sedang Diberikan Materi dengan VBA Excel

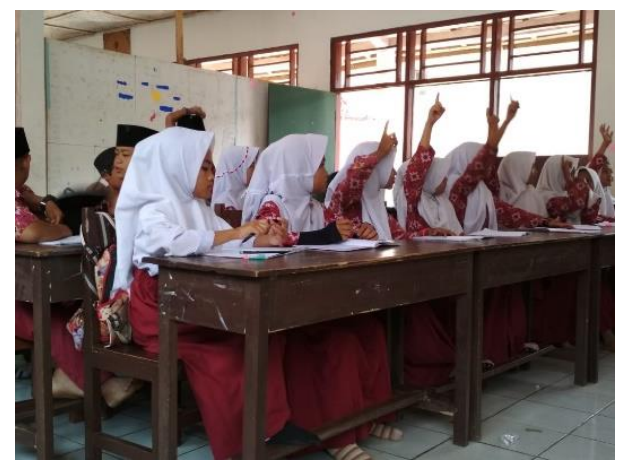

Gambar 2. Siswa Aktif Selama Proses Pembelajaran

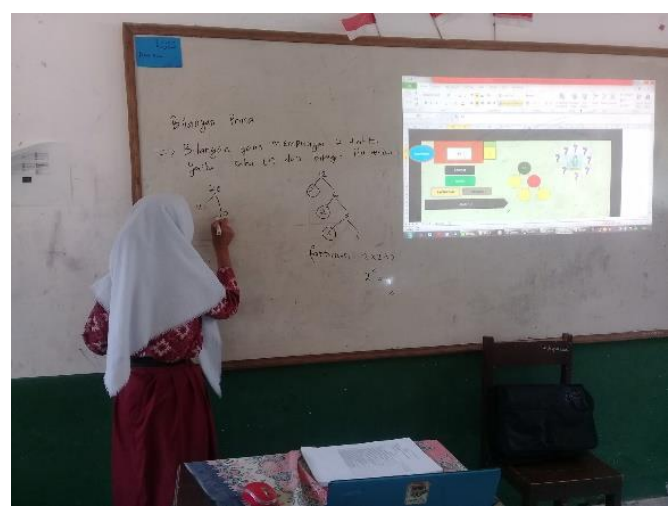

Gambar 3. Siswa berani mengerjakan soal ke depan 
Berdasarkan hasil penelitian yang dilakukan pada siswa kelas 5 di MI II Celakpeneliti melakukan pengolahan data dan diperoleh hasil berikut ini:

Tabel 4. Persentase Skala Sikap Minat Belajar

\begin{tabular}{clccccc}
\hline \multirow{2}{*}{ No } & \multicolumn{1}{c}{ Indikator } & \multirow{2}{*}{$\begin{array}{c}\text { Banyak } \\
\text { Pernyataan }\end{array}$} & & \multicolumn{4}{c}{ Total } & \multirow{2}{*}{ Kategori } \\
\cline { 4 - 6 } & & 4 & 362 & 13.92 & $87.02 \%$ & Sangat tinggi \\
\hline 1 & Perasaan senang & 4 & 371 & 14.27 & $89.18 \%$ & Sangat tinggi \\
\hline 2 & Ketertarikan siswa & 4 & 304 & 11.69 & $73.08 \%$ & sedang \\
\hline 3 & Keterlibatan siswa & 4 & 308 & 11.85 & $74.04 \%$ & tinggi \\
\hline \multirow{2}{*nnnnnnn}{4} & $\begin{array}{l}\text { rajin dalam belajar dan } \\
\text { rajin dalam mengerjakan } \\
\text { tugas matematika }\end{array}$ & 4 & 322 & 12.38 & $77.40 \%$ & tinggi \\
\hline 5 & $\begin{array}{l}\text { Tekun dan disiplin } \\
\text { dalam belajar dan memiliki } \\
\text { jadwal belajar }\end{array}$ & 4 & & & & \\
\hline
\end{tabular}

Berdasarkan Tabel 4, menunjukan bahwa indikator perasaan senang memperoleh persentase rata-rata yaitu $87,02 \%$ dengan kategori sangat tinggi, indikator ketertarikan siswa memperoleh persentase rata-rata $89,18 \%$ dengan kategori sangat tinggi, indikator keterlibatan siswa memperoleh persentase rata-rata $73,08 \%$ dengan kategori sedang, indikator rajin dalam belajar dan rajin dalam mengerjakan tugas matematika memperoleh persentase rata-rata 74,04 dengan kategori tinggi, dan indikator tekun dan disiplin dalam belajar dan memiliki jadwal belajar memperoleh persentase ratarata $77,04 \%$ dengan kategori tinggi.

Secara grafis, Tabel 4 dapat disajikan sebagai diagram yang ditunjukkan oleh Gambar 4.

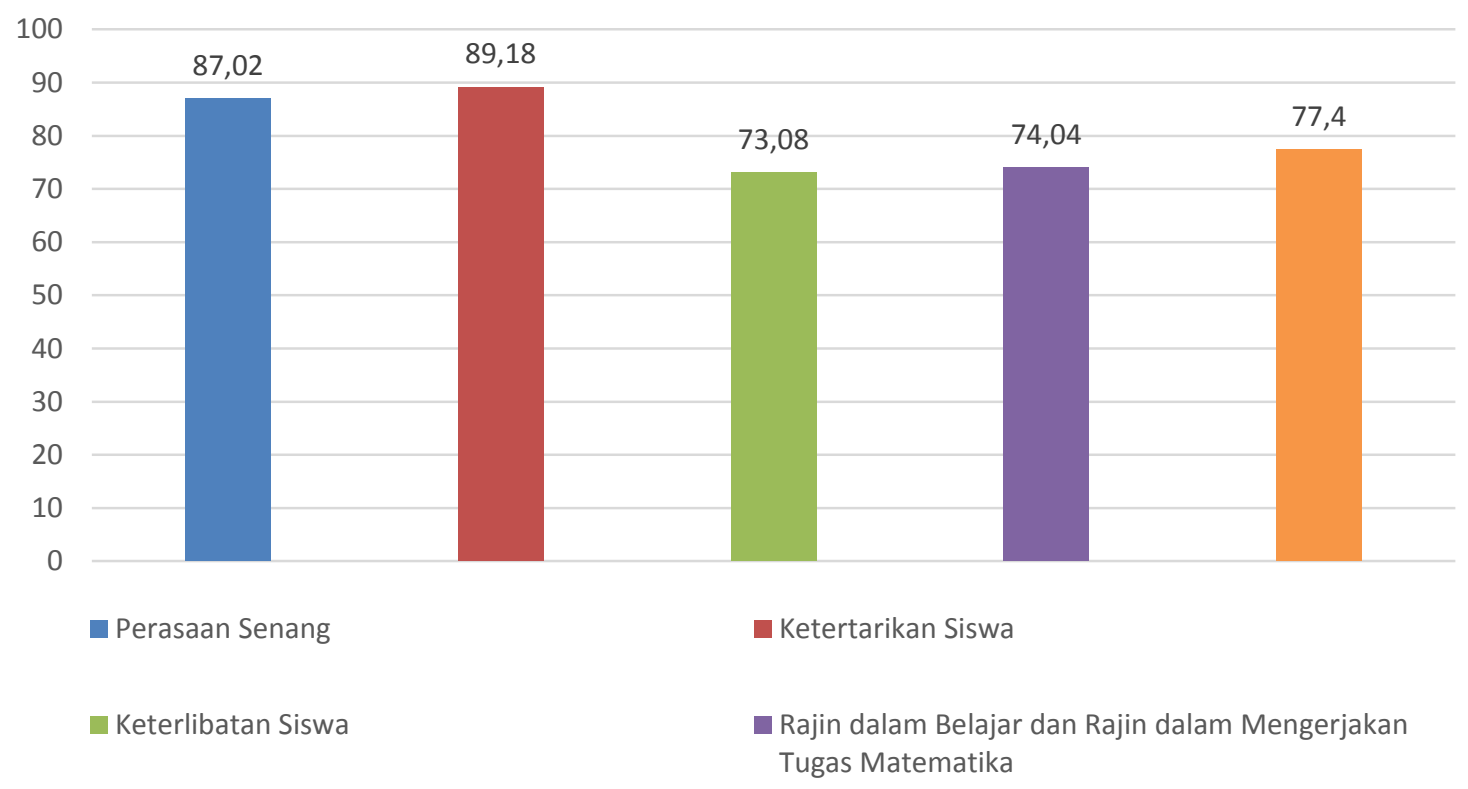

- Tekun dan Disiplin dalam Belajar dan Memiliki Jadwal Belaiar

Gambar 4. Diagram Minat Belajar Matematika Siswa Menggunaan Visual Basic Application

Hasil pada penelitian ini menunjukan bahwa respon siswa dalam pembelajaran matematika menggukan aplikasi VBA itu sangat positif. Hal tersebut ditunjukan oleh persentase rata-rata yang masuk kategori sedang, tinggi dan sangat tinggi. Dengan kata lain penggunaan aplikasi VBA dapat meningkatkan minat siswa dalam belajar matematika. Hal tersebut sejalan dengan hasil penelitian 
yang dilakukan Romlah et al., (2019) bahwa penggunaan aplikasi VBA dalam pembelajaran matematika dapat meningkatkan motivasi siswa dalam belajar.

Aplikasi VBA merupakan salah satu media pembelajaran yang bisa dibilang sesuatu yang baru bagi siswa SD pada umumnya. Sehingga ketika media tersebut digunakan dalam pembelajaran dapat menarik siswa untuk memperhatikan dan mengikuti pembelajaran dengan baik. Hal tersebut seperti yang dikemukakan oleh Senjayawati (Romlah et al., 2019) bahwa pembelajaran berbasis ICT VBA Excel lebih menarik dan menambah motivasi siswa dalam belajar matematika dan meningkatkan hasil belajar siswa. Oleh karena itu, penggunaan media pembelajaran khususnya aplikasi VBA dapat meningkatkan minat siswa untuk belajar matematika, sehingga penggunaan media pembelajaran bisa menjadi salah satu alternatif guru untuk menciptakan pembelajaran yang lebih menarik dan inovatif.

\section{SIMPULAN}

Berdasarkan hasil pengolahan data dari angket yang dijawab siswa, dapat disimpulkan bahwa pembelajaran matematika berbantuan media ICT VBA dapat meningkatkan minat belajar siswa. Sehingga dengan begitu, penggunaan media ICT VBA dapat menjadi salah satu alternatif untuk menjadikan pembelajaran lebih menarik dan menyenangkan. Hal tersebut sejalan dengan yang dinyatakan oleh Chotimah, Bernard, \& Wulandari, (Nurfauziah \& Fitriani, 2019) VBA Excelmerupakan aplikasi yang dirancang menjadi alat matematika yang menjadikan siswamenjadi lebih aktif, tidak perlu biaya, dan Microsoft office excel dapat diakses olehpengguna computer. Dengan menggunakan media pembelajaran ini diharapkan bisa memberikan manfaat untuk memperlancar interaksi antara guru dengan siswa sehingga pembelajaranakan lebih efektif dan efisien (Samura, 2015).

\section{DAFTAR PUSTAKA}

Kemendikbud. (2014). Implementasi Kurikulum 2013 Konsep dan Penerapan. Kementrian Pendidikan Dan Kebudayaan.

Bernard, M. (2018). Meningkatkan Kemampuan Berpikir Kreatif Mahasiswa Matematik Melalui Pendekatan Problem Posing Berbantuan Visual Basic Application For Excel. JPMI-Jurnal Pembelajaran Matematika Inovatif, 1(1), 69-78. https://doi.org/10.22460/jpmi.v1i3.219-228

Dores, O. J., Huda, F. A., Riana, R., \& Persada, S. (2019). Analisis Minat Belajar Matematika Siswa Kelas IV Sekolah Dasar Negeri 4 Sirang Setambang Tahun Pelajaran 2018/2019. J-PIMat, 1(1), $38-48$.

Hanipa, A., Misbahudin, A. R., Andreansyah, \& Setiawan, W. (2019). Analisis Minat Belajar Siswa MTs Kelas VIII dalam Pembelajaran Melalui Aplikasi Geogebra. JPMI-Jurnal Pembelajaran Matematika Inovatif, 2(5), 315-322.

Nurfauziah, P., \& Fitriani, N. (2019). Gender dan Resiliensi Matematis Siswa SMP dalam Pembelajaran Scientific Berbantuan VBA Excel. Symmetry-Pasundan Journal of Research in Mathematics Learning and Education, 4, 28-37.

Putri, A. D., Hasnita, S., Vilardi, M., \& Setiawan, W. (2019). Analisis Pengaruh Minat Belajar Siswa MA dengan Menggunakan Aplikasi Geogebra pada Materi SPLDV. Edumatica, 09(April), 4752.

Rahmawati, N. S., Bungsu, T. K., Islamiah, I. D., \& Setiawan, W. (2015). Analisis Minat Belajar Siswa MA Al-Mubarok Melalui Pendekatan Saintifik Berbantuan Aplikasi Geogebra pada Materi Statistika Dasar. Journal On Education, 01(03), 386-395.

Romlah, S., Nugraha, N., Nurjanah, S., \& Setiawan, W. (2019). Analisis Motivasi Belajar Siswa SD Albarokah 448 Bandung dengan Menggunakan Media ICT Berbasis For VBA Excel pada Materi Garis Bilangan. Jurnal Cendekia: Jurnal Pendidikan Matematika, 3(1), 220-226. 
Samura, A. O. (2015). Penggunaan Media dalam Pembelajaran Matematika dan Manfaatnya. DeltaPi: Jurnal Matematika Dan Pendidikan Matematika, 4(1), 69-79.

Widyastuti, Wijaya, A. P., Rumite, W., \& Marpaung, R. R. T. (2019). Minat Siswa Terhadap Matematika dan Hubungannya dengan Metode Pembelajaran dan Efikasi Diri. Jurnal Pendidikan Matematika, 13(1), 83-100. 